\title{
In Vitro Anticancer MCF-7, Anti-Inflammatory, and Brine Shrimp Lethality Assay (BSLA) and GC-MS Analysis of Whole Plant Butanol Fraction of Rheum ribes (WBFRR)
}

\author{
Jahangir Khan Achakzai (iD, ${ }^{1}$ Muhammad Anwar Panezai, \\ Muhammad Ayub Kakar, ${ }^{1}$ Abdul Manan Kakar, ${ }^{1}$ Shahabuddin Kakar, ${ }^{2}$ Javed Khan, ${ }^{3}$ \\ Nazima Yousaf Khan, ${ }^{1}$ Inayatullah Khilji, ${ }^{1}$ and Ajab Khan Tareen ${ }^{1}$ \\ ${ }^{1}$ Institute of Biochemistry, University of Balochistan, Quetta 87300, Pakistan \\ ${ }^{2}$ Department of Zoology, University of Balochistan, Quetta 87300, Pakistan \\ ${ }^{3}$ Department of Microbiology, Quaid-i-Azam University, Islamabad 45320, Pakistan
}

Correspondence should be addressed to Jahangir Khan Achakzai; jahangir.biochemist@yahoo.com

Received 16 April 2019; Accepted 4 June 2019; Published 23 June 2019

Academic Editor: Jane Hanrahan

Copyright (C) 2019 Jahangir Khan Achakzai et al. This is an open access article distributed under the Creative Commons Attribution License, which permits unrestricted use, distribution, and reproduction in any medium, provided the original work is properly cited.

In this study, GC-MS analysis has shown that whole plant butanol fraction of rheum ribes (WBFRR) comprises of 21 compounds

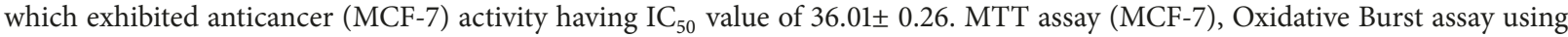
chemiluminescence technique, and B-Hatching techniques were the methods used for anticancer MCF-7, anti-inflammatory, and Brine Shrimp Lethality Assay (BSLA). GC-MS was used for structural elucidation. Whole plant methanol extract of rheum ribes (WMERR), whole plant $\mathrm{n}$-hexane fraction of rheum ribes (WHFRR), and whole plant aqueous fraction of rheum ribes (WAFRR) were inactive against anticancer (MCF-7) cell line. Whole plant methanol extract of rheum ribes (WMERR), whole plant aqueous fraction of rheum ribes (WAFRR) and whole plant butanol fraction of rheum ribes (WBFRR) showed anti-inflammatory activity on ROS having $\mathrm{IC}_{50}$ value of $23.2 \pm 1.9,24.2 \pm 2.7$ and $12.0 \pm 0.6$. Whole plant butanol fraction of rheum ribes (WBFRR) showed Brine Shrimp Lethality with LD50 693.302 while whole plant methanol extract of rheum ribes (WMERR) and whole plant aqueous fraction of rheum ribes (WAFRR) showed high lethality at highest concentration. This study revealed that whole plant butanol fraction of rheum ribes (WBFRR) exhibited significant anticancer (MCF-7) activity. In the near future, the constituent of whole plant butanol fraction of rheum ribes (WBFRR) can be the alternative drug against MCF-7 cell line with least toxicity and side effects.

\section{Introduction}

Rheum ribes, the subtropical and temperate regional plant, belongs to Polygonaceae family. The English name of this plant is rhubarb which is of three types, for instance, the Rhapontic rhubarb, the Himalayan or Indian rhubarb, and the Chinese rhubarb [1]. Plenty of active phytochemical and crude drugs are present in this plant of Asian countries [2]. The biologically active phytochemicals are flavonoids (quercetin 3-O-rutinoside, quercetin 3-O-rhamnoside, quercetin 3-O-galactoside, and catechin), anthocyanins (cyaniding 3glucoside and cyaniding 3-rutinoside), stilbene (desoxyrhapontigenin and trans-rhapontigenin), and anthraquinones (emodin, physcion, aloe-emodin, chrysophanol, and rhein). Ethnomedicinal properties of rheum ribes are laxative, antioxidative, analgestic, antidiabetic, antimutagenic, ascathartic, anti-inflammatory, anticancer, antibacterial, hepatoprotective, antiplatelet, diarrhea, measles, cholagogue, stomachic, smallpox, hemorrhoids, antiemetic, and antipsoriatic [3-10]. In this research study, anticancer MCF-7, antiinflammatory, and Brine Shrimp Lethality Assay (BSLA) and GC-MS analysis are analyzed.

\section{Materials and Methods}

\subsection{Plant Material}

2.2. Extraction. The plant rheum ribes was collected from the mountains of Chaman, Balochistan, Pakistan, and identified 
by a taxonomist Prof. Dr. Rasool Bakhsh Tareen, Department of Botany, University of Balochistan, Quetta, Pakistan. 3kg whole plant of rheum ribes was dried in shade and then grinded, soaked in 5 liter of methanol, kept for 7 days, and shaken daily. After a 7-day period, methanol containing whole plant of rheum ribes was filtered and vaporized with the help of rotary evaporator. Dried semisolid whole plant methanolic extract of rheum ribes (WMERR) was $48.6 \mathrm{gm}$. This crude extract $11.5 \mathrm{gm}$ was examined for anticancer MCF-7, anti-inflammatory, and Brine Shrimp Lethality Assay (BSLA) while the remaining extract was fractionated with solvents, for instance, $n$-hexane, aqueous, and butanol.

2.3. Fractionation of Crude Extract. In a separatory funnel, with crude extract two solvents were added such as aqueous and n-hexane. The separatory funnel was shaken thoroughly to create two layers such as aqueous layer and n-hexane layer. Both solvents were separately vaporized with the help of rotary evaporator to form whole plant n-hexane fraction of rheum ribes (WHFRR) $0.1 \mathrm{gm}$ and whole plant aqueous fraction of rheum ribes (WAFRR) $23.6 \mathrm{gm}$. Both fractions were examined for anticancer MCF-7, anti-inflammatory, and Brine Shrimp Lethality Assay (BSLA) while whole plant aqueous fraction of rheum ribes (WAFRR) was further fractionated with a solvent such as butanol $[11,12]$.

2.4. Fractionation of Whole Plant Aqueous Fraction of rheum ribes (WAFRR). Whole plant aqueous fraction of rheum ribes (WAFRR) was fractionated with solvent such as butanol.

2.5. Formation of Whole Plant Butanol Fraction of rheum ribes (WBFRR). In a separatory funnel, with whole plant aqueous fraction of rheum ribes (WAFRR), two solvents were added such as butanol and aqueous. The separatory funnel was shaken thoroughly to create two layers such as butanol layer and aqueous layer. Both solvents were separately vaporized with the help of rotary evaporator to form whole plant butanol fraction of rheum ribes (WBFRR) $2.5 \mathrm{gm}$ and whole plant aqueous fraction of rheum ribes (LAFRR). Whole plant butanol fraction of rheum ribes (WBFRR) was examined for anticancer MCF-7, anti-inflammatory, and Brine Shrimp Lethality Assay (BSLA) [11, 12].

2.6. MTT Assay (MCF-7 Cell Lines). In this assay, Dulbecco's Eagle modified medium, containing ten percent fetal bovine serum, was used for the culturing of MCF-7 cell lines which were then kept in five percent $\mathrm{CO}_{2}$ and incubated at $37^{\circ} \mathrm{C}$. MCF-7 cells were collected when confluency was developed and 8000 cells per well were plated in 96 well flat. After 24 hours, the extracts and fractions with $50 \mathrm{ug} / \mathrm{ml}$ were added and then incubated for 48 hours. After incubation, extracts and fractions were removed. To each well, $0.5 \mathrm{mg} / \mathrm{ml} \mathrm{MTT}$ was added and kept in incubator for 3 hours at $37^{\circ} \mathrm{C}$. MTT was reduced into Formazan crystals which was then dissolved in 100ul DMSO and at $570 \mathrm{~nm}$ absorbance was taken using micro-plate reader (Spectra Max plus, Molecular Devices, CA, USA). In this assay, doxorubicin was used as a standard drug. The decrease in viable cells or percent inhibition was calculated with the help of following formula:
$\%$ Inhibition $=100-($ mean of O.D. of test compound mean of O.D. of negative control)/(mean of O.D. of positive control - mean of O.D. of negative control) x 100)

For the calculation of $\mathrm{IC}_{50} 20 \mathrm{mM}$ stock solution of extracts and fractions was diluted into working solution with $50 \mathrm{uM}$ and then in order to get less than 50 percent inhibition, working solution was further diluted in serial dilutions. With the help of EZ-fit5 software, IC50 was calculated [13].

\subsection{Anti-Inflammatory Assay}

Oxidative Burst Assay Using Chemiluminescence Technique. In this technique, 25 ul diluted whole blood $\mathrm{HBSS}^{++}$and $25 \mathrm{ul}$ of extracts and fractions were incubated for $15 \mathrm{~min}$ at $37^{\circ} \mathrm{C}$ and then plated in 96 well plates. Control wells contain $\mathrm{HBSS}^{++}$ and cells while blank wells contain $\mathrm{HBSS}^{++} .25$ ul luminol and $25 \mathrm{ul}$ serum opsonized zymosan were added into each well. In terms of relative light units, the level of ROS was recorded in luminometer. In this assay, Ibuprofen with $\mathrm{IC}_{50} 11.2 \pm 1.9$ is used as a standard drug [14].

\subsection{Brine Shrimp Lethality Assay}

B-Hatching Techniques. Scatter $50 \mathrm{mg}$ of brine shrimp eggs in a hatching tray which was already half filled with filtered brine solution. Put it in incubator at $23^{\circ} \mathrm{C}$. Take $20 \mathrm{mg}$ of extracts and fraction and dissolve it in $2 \mathrm{ml}$ of solvent. Transfer 5,50 , and $500 \mathrm{ul}$ from this solution to 3 vials. Leave them overnight to allow the solvent to evaporate. With the help of Pasteur pipette put 10 larvae per each vial. Add $5 \mathrm{ml}$ seawater. Under illumination, for 24 hours, incubate them at $25-27^{\circ} \mathrm{C}$. For positive and negative controls, add reference cytotoxic drug along with solvent in other vials. For the determination of $\mathrm{LD}_{50}$, Finney computer program was used [15-17].

2.9. Gas Chromatography Mass Spectrometry (GC-MS) Analysis: Triple Quadrupole Acquisition Method MS Parameters. For identification and quantification of rheum ribes compounds, 2 ul of rheum ribes extract or fraction was directly injected into the gas chromatograph mod.6890N Network GC System (Agilent Technologies Palo Alto, CA) together in the presence of mass spectrometer mod. 5973 Network Mass Selective Detector (Agilent Technologies Palo Alto, CA) and furnished in the presence of a column HP-5MS $(30 \mathrm{~m}$ length, $0.25 \mathrm{~mm}$ interior diameter, $0.25 \mathrm{um}$ film width Agilent Technologies, Palo Alto, CA). Helium gas was off. Injection was made into a split-splitless injector (split ratio 30:1) at $250^{\circ} \mathrm{C}$. The oven program was as follows: $70^{\circ} \mathrm{C}$ for $3 \mathrm{~min}$, then $6^{\circ} \mathrm{C} / \mathrm{min}$ to 180 for $5 \mathrm{~min}$, then $6^{\circ} \mathrm{C} / \mathrm{min}$ to $280^{\circ} \mathrm{C}$ for $10 \mathrm{~min}$, then $8^{\circ} \mathrm{C} / \mathrm{min}$ to $290^{\circ} \mathrm{C}$ for $20 \mathrm{~min}$. The MSD transfer line was set at a temperature of $250^{\circ} \mathrm{C}$; MSD temperature quadrupole was of $150^{\circ} \mathrm{C}$ and ionization temperature was $230^{\circ} \mathrm{C}$; mass spectra were seventy electrovolts and scan achievement was accomplished in the series between thirty five and $300 \mathrm{~m} / \mathrm{z}$. The identification of the components of the rheum ribes extract or fraction was assigned by matching their mass spectra with those available in the libraries NIST 02 and WILEY [18].

\section{Results and Discussion}

MCF-7 cell line results have shown that whole plant butanol fraction of rheum ribes (WBFRR) exhibited anticancer 
TABLE 1: Anticancer Assay (MCF-7) of extracts and fractions of whole plant of Rheum ribes.

\begin{tabular}{lcccc}
\hline S.No. & Extract/Fraction/Std. Drug & Conc. $(\mathrm{ug} / \mathrm{ml})$ & \% Inhibition/Stimulation & IC50 \pm S.D. \\
\hline 1 & WMERR & 50 & 38.17 & Inactive \\
\hline 2 & WHFRR & 50 & 22.46 & Inactive \\
\hline 3 & WAFRR & 50 & 9.90 & Inactive \\
\hline 4 & WBFRR & 50 & 93.15 & $36.01 \pm 0.26$ \\
\hline 5 & Doxorubicin & 50 & 73.23 & $0.80 \pm 0.05$ \\
\hline
\end{tabular}

TABLE 2: Anti-inflammatory activities of extracts and fractions of whole plant of Rheum ribes.

\begin{tabular}{lcccc}
\hline S.NO & Extract/Fraction/Std. Drug & Conc. $(\mathrm{ug} / \mathrm{ml})$ & \% Inhibition/Stimulation & IC50 \pm S.D. \\
\hline 1 & WMERR & $250,50,10$ & - & $23.2 \pm 1.9$ \\
\hline 2 & WHFRR & $250,50,10$ & - & - \\
\hline 3 & WAFRR & $250,50,10$ & - & $24.2 \pm 2.7$ \\
\hline 4 & WBFRR & $250,50,10$ & - & $12.0 \pm 0.6$ \\
\hline 5 & Ibuprofen & & $11.2 \pm 1.9 \mathrm{ug} / \mathrm{ml}$ \\
\hline
\end{tabular}

TABLE 3: Brine Shrimp Lethality Bioassay of Whole plant Methanol Extract of Rheum ribes (WMERR).

\begin{tabular}{|c|c|c|c|c|c|}
\hline Dose (ug/ml) & No. of Shrimps & No. of Survivors & LD50 (ug/ml) & STD. Drug & LD50 (ug/ml) \\
\hline 10 & 30 & 28 & & & \\
\hline 100 & 30 & 27 & - & Etoposide & 7.4625 \\
\hline 1000 & 30 & 00 & & & \\
\hline
\end{tabular}

TABLE 4: Brine Shrimp Lethality Bioassay of Whole Plant n-Hexane Fraction of Rheum ribes (WHFRR).

\begin{tabular}{lcccc}
\hline Dose $(\mathrm{ug} / \mathrm{ml})$ & No. of Shrimps & No. of Survivors & LD50 (ug/ml) & STD. Drug \\
\hline 10 & 30 & 28 & & LD50 (ug/ml) \\
100 & 30 & 24 & - & Etoposide \\
1000 & 30 & 00 & & 7.4625 \\
\hline
\end{tabular}

TABLE 5: Brine Shrimp Lethality Bioassay of Whole Plant Aqueous Fraction of Rheum ribes (WAFRR).

\begin{tabular}{|c|c|c|c|c|c|}
\hline Dose (ug/ml) & No. of Shrimps & No. of Survivors & LD50 (ug/ml) & STD. Drug & LD50 (ug/ml) \\
\hline 10 & 30 & 29 & & & \\
\hline 100 & 30 & 24 & - & Etoposide & 7.4625 \\
\hline 1000 & 30 & 00 & & & \\
\hline
\end{tabular}

TABLE 6: Brine Shrimp Lethality Bioassay of Whole Plant Butanol Fraction of Rheum ribes (WBFRR).

\begin{tabular}{|c|c|c|c|c|c|}
\hline Dose (ug/ml) & No. of Shrimps & No. of Survivors & LD50 (ug/ml) & STD. Drug & LD50 (ug/ml) \\
\hline 10 & 30 & 30 & & & \\
\hline 100 & 30 & 29 & 693.302 & Etoposide & 7.4625 \\
\hline 1000 & 30 & 11 & & & \\
\hline
\end{tabular}

activity against MCF-7 cell line with $\mathrm{IC}_{50}$ value of $36.01 \pm 0.26$. Whole plant methanol extract of rheum ribes (WMERR), whole plant $\mathrm{n}$-hexane fraction of rheum ribes (WHFRR), and whole plant aqueous fraction of rheum ribes (WAFRR) were inactive against anticancer (MCF-7) cell line. The anticancer activities (MCF-7 cell line) of extract and fractions of whole plant of rheum ribes are shown in Table 1.

Whole plant methanol extract of rheum ribes (WMERR), whole plant aqueous fraction of rheum ribes (WAFRR), and whole plant butanol fraction of rheum ribes (WBFRR) showed anti-inflammatory activity on ROS having $\mathrm{IC}_{50}$ value of $23.2 \pm 1.9,24.2 \pm 2.7$ and $12.0 \pm 0.6$. The anti-inflammatory activities of extract and fractions of rheum ribes are shown in Table 2.

whole plant butanol fraction of rheum ribes (WBFRR) showed Brine shrimp lethality with LD50 693.302 while whole plant methanol extract of rheum ribes (WMERR) and whole plant aqueous fraction of rheum ribes (WAFRR) showed high lethality at highest concentration. Brine shrimp lethality assay of extract and fractions of rheum ribes is shown in Tables 3-6.

Molecular formula, molecular mass, structure, and RT of compounds 1-21 of whole plant butanol fraction of rheum ribes (WBFRR) are shown in Tables $7-10$ while mass spectra 
TABLE 7: Molecular formula, molecular mass, structure, and RT of compounds 1-5 whole plant butanol fraction of rheum ribes (WBFRR).

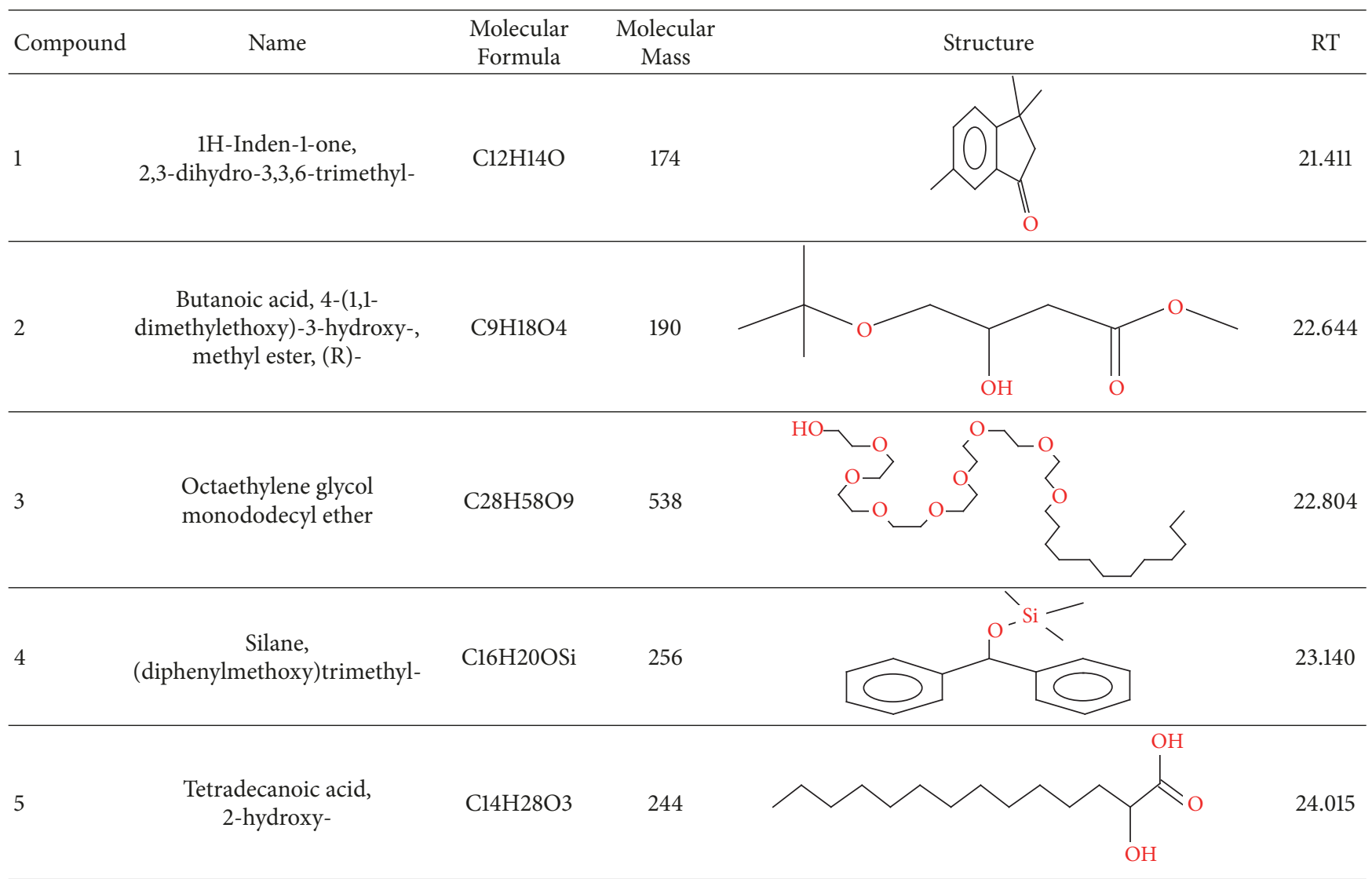

TABLE 8: Molecular formula, molecular mass, structure, and RT of compounds 6-10 whole plant butanol fraction of rheum ribes (WBFRR).

\begin{tabular}{|c|c|c|c|c|c|}
\hline Compound & Name & $\begin{array}{c}\text { Molecular } \\
\text { Formula }\end{array}$ & $\begin{array}{c}\text { Molecular } \\
\text { Mass }\end{array}$ & Structure & RT \\
\hline 6 & $\begin{array}{l}\text { Butanedioic acid, } \\
\text { dibutyl ester }\end{array}$ & $\mathrm{C} 12 \mathrm{H} 22 \mathrm{O} 4$ & 230 & & 25.151 \\
\hline 7 & $\begin{array}{l}\text { Butanedioic acid, } \\
\text { hydroxy-, dibutyl } \\
\text { ester, }( \pm)-\end{array}$ & $\mathrm{C} 12 \mathrm{H} 22 \mathrm{O} 5$ & 246 & $\mathrm{OH}$ & 26.902 \\
\hline 8 & Pipradrol & $\mathrm{C} 18 \mathrm{H} 21 \mathrm{NO}$ & 267 & & 27.076 \\
\hline 9 & Tetradecanoic acid & $\mathrm{C} 14 \mathrm{H} 28 \mathrm{O} 2$ & 228 & & 30.280 \\
\hline 10 & $\begin{array}{l}\text { n-Hexadecanoic } \\
\text { acid }\end{array}$ & $\mathrm{C} 16 \mathrm{H} 32 \mathrm{O} 2$ & 256 & & 39.870 \\
\hline
\end{tabular}


TABLE 9: Molecular formula, molecular mass, structure, and RT of compounds 11-15 whole plant butanol fraction of rheum ribes (WBFRR).

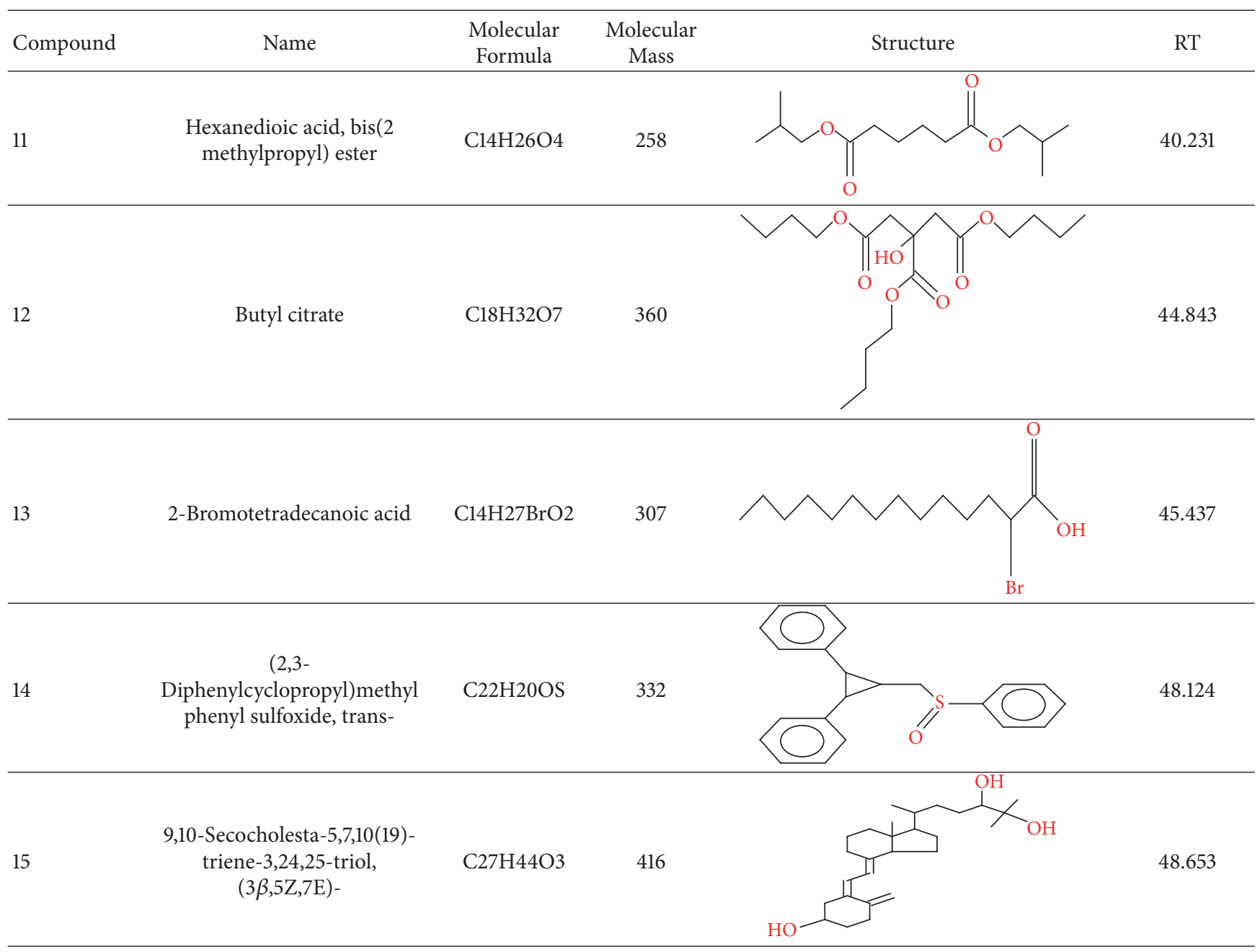

interpretation of compounds 1-21 of whole plant butanol fraction of rheum ribes (LBFRR) is presented in Tables 11-14.

\section{Conclusion}

In this study, GC-MS analysis has shown that whole plant butanol fraction of rheum ribes (WBFRR) is composed of 21 compounds which exhibited anticancer (MCF-7) activity having $\mathrm{IC}_{50}$ value of $36.01 \pm 0.26$. Whole plant methanol extract of rheum ribes (WMERR), whole plant n-hexane fraction of rheum ribes (WHFRR), and whole plant aqueous fraction of rheum ribes (WAFRR) were inactive against anticancer (MCF-7) cell line.

Whole plant methanol extract of rheum ribes (WMERR), whole plant aqueous fraction of rheum ribes (WAFRR), and whole plant butanol fraction of rheum ribes (WBFRR) showed anti-inflammatory activity on ROS having $\mathrm{IC}_{50}$ value of $23.2 \pm 1.9,24.2 \pm 2.7$, and $12.0 \pm 0.6$.

Whole plant butanol fraction of rheum ribes (WBFRR) showed Brine shrimp lethality with LD50 693.302 while whole plant methanol extract of rheum ribes (WMERR) and whole plant aqueous fraction of rheum ribes (WAFRR) showed high lethality at highest concentration.

This study revealed that whole plant butanol fraction of rheum ribes (WBFRR) exhibited significant anticancer MCF-7 activity. In the near future, the constituent of whole plant butanol fraction of rheum ribes (WBFRR) can be the alternative drug against MCF-7 cell line with the least toxicity and side effects.

\section{Data Availability}

The data used to support the findings of this study are available from the corresponding author upon request.

\section{Conflicts of Interest}

The authors declare that there are no conflicts of interest. 
TABLE 10: Molecular formula, molecular mass, structure, and RT of compounds 16-21 whole plant butanol fraction of rheum ribes (WBFRR).

\begin{tabular}{|c|c|c|c|c|c|}
\hline Compound & Name & $\begin{array}{l}\text { Molecular } \\
\text { Formula }\end{array}$ & $\begin{array}{l}\text { Molecular } \\
\text { Mass }\end{array}$ & Structure & RT \\
\hline 16 & Ethyl iso-allocholate & $\mathrm{C} 26 \mathrm{H} 44 \mathrm{O} 5$ & 436 & & 54.708 \\
\hline 17 & $\begin{array}{c}\beta \text {-D-Mannofuranoside, } \\
\text { 2,3:5,6-DI-O-ethylboranediyl- } \\
\text { 1-O-(stigmasta-5, } \\
\text { 22-dien-3-yl)- }\end{array}$ & C39H64B2O6 & 650 & & 55.215 \\
\hline 18 & $\begin{array}{l}\text { 9,19-Cyclolanost-24-en-3-ol, } \\
\text { acetate, }(3 \beta) \text { - }\end{array}$ & $\mathrm{C} 32 \mathrm{H} 52 \mathrm{O} 2$ & 468 & & 55.985 \\
\hline 19 & Stigmastan-3,5-diene & $\mathrm{C} 29 \mathrm{H} 48$ & 396 & & 56.278 \\
\hline 20 & Vitamin $\mathrm{E}$ & $\mathrm{C} 29 \mathrm{H} 50 \mathrm{O} 2$ & 430 & & 56.655 \\
\hline 21 & $\begin{array}{l}\text { 9,19-Cyclolanost-24-en-3-ol, } \\
\text { acetate, }(3 \beta) \text { - }\end{array}$ & $\mathrm{C} 32 \mathrm{H} 52 \mathrm{O} 2$ & 468 & & 57.338 \\
\hline
\end{tabular}

TABLE 11: Mass spectra of compounds 1-5 of whole plant butanol fraction of rheum ribes (LBFRR).

\begin{tabular}{lc}
\hline Compound & $\mathrm{m} / \mathrm{z}(\%$ relative abundance $)$ \\
\hline 1 & $\left.174\left(\mathrm{M}^{+}\right], 300\right), 160(125), 159(999), 131(90), 116(110), 115(172), 91(107), 51(86), 39(116), 27(80)$ \\
\hline 3 & $190\left(\mathrm{M}^{+}\right), 117(238), 104(188), 103(466), 85(191), 71(167), 59(134), 57(999), 43(454), 41(287), 29(219)$ \\
\hline 4 & $538\left(\mathrm{M}^{+}\right), 89(468), 87(229), 73(351), 71(213), 59(182), 57(384), 45(999), 44(232), 43(338), 29(196)$ \\
\hline 5 & $256(\mathrm{M}+], 378), 241(218), 179(444), 178(240), 168(176), 167(999), 165(400), 152(180), 73(680), 45(244)$ \\
\hline
\end{tabular}

TABLE 12: Mass spectra of compounds 6-10 of whole plant butanol fraction of rheum ribes (LBFRR).

\begin{tabular}{lc}
\hline Compound & $\mathrm{m} / \mathrm{z}(\%$ relative abundance $)$ \\
\hline 6 & $230\left(\mathrm{M}^{+}\right), 157(148), 102(45), 101(999), 57(180), 56(159), 55(67), 41(167), 29(133), 28(72), 27(49)$ \\
\hline 7 & $246\left(\mathrm{M}^{+}\right), 173(78), 145(304), 117(170), 90(155), 89(999), 71(214), 57(554), 56(143), 41(262), 29(251)$ \\
\hline 9 & $267\left(\mathrm{M}^{+}\right), 182(16), 165(24), 152(15), 105(69), 85(50), 84(999), 82(12), 77(73), 56(50), 55(12)$ \\
\hline 10 & $228\left(\mathrm{M}^{+}\right), 129(371), 85(241), 73(999), 71(338), 69(282), 60(841), 57(609), 55(451), 43(681), 41(461)$ \\
\hline
\end{tabular}


TABLE 13: Mass spectra of compounds 11-15 of whole plant butanol fraction of rheum ribes (LBFRR).

\begin{tabular}{lc}
\hline Compound & $\mathrm{m} / \mathrm{z}(\%$ relative abundance $)$ \\
\hline 11 & $258\left(\mathrm{M}^{+}\right), 185(585), 129(999), 111(264), 101(136), 100(124), 57(463), 56(225), 55(216), 41(216), 29(145)$ \\
\hline 12 & $360\left(\mathrm{M}^{+}\right), 259(159), 186(103), 185(999), 129(676), 111(104), 57(180), 56(86), 43(59), 41(200), 29(118)$ \\
\hline 14 & $307\left(\mathrm{M}^{+}\right), 99(339), 83(299), 73(436), 69(386), 57(616), 55(712), 43(946), 41(999), 29(473), 27(296)$ \\
\hline 15 & $332\left(\mathrm{M}^{+}\right), 207(238), 193(89), 130(103), 129(959), 128(137), 117(83), 115(160), 92(57), 91(999), 77(98)$ \\
\hline
\end{tabular}

TABLE 14: Mass spectra of compounds 16-21 of whole plant butanol fraction of rheum ribes (LBFRR).

\begin{tabular}{|c|c|}
\hline Compound & $\mathrm{m} / \mathrm{z}$ ( \% relative abundance) \\
\hline 16 & 436( $\left(\mathrm{M}^{+}\right), 83(460), 81(547), 69(609), 57(797), 55(914), 44(492), 43(999), 41(867), 29(476), 17(469)$ \\
\hline 17 & $650\left(\mathrm{M}^{+}\right), 395(282), 394(440), 255(268), 111(255), 99(245), 83(999), 81(256), 69(441), 57(256), 55(430)$ \\
\hline 18 & $468\left(\mathrm{M}^{+}\right), 121(278), 109(324), 107(311), 95(456), 93(260), 81(316), 69(752), 55(485), 43(999), 41(572)$ \\
\hline 19 & $\begin{array}{l}\left.\left.\text { 397(M+1], 165), 396( } \mathrm{M}^{+}\right], 547\right), \text { 147(201), } 145(157), 105(167), 81(233), 57(269), 55(291), 43(999) \\
41(209)\end{array}$ \\
\hline 20 & 430(M $\left.\left.\mathrm{M}^{+}\right], 318\right), 166(117), 165(999), 164(326), 85(135), 71(226), 57(410), 55(185), 43(419), 41(171)$ \\
\hline 21 & $468\left(\mathrm{M}^{+}\right), 121(278), 109(324), 107(311), 95(456), 93(260), 81(316), 69(752), 55(485), 43(999), 41(572)$ \\
\hline
\end{tabular}

\section{Acknowledgments}

The authors are thankful to Hussain Ebrahim Jamal (HEJ), Research Institute of Chemistry, University of Karachi, Karachi, Pakistan, for providing anticancer MCF-7, antiinflammatory, and Brine Shrimp Lethality assay and GCMS analysis and Institute of Biochemistry, University of Balochistan, Quetta, Pakistan, for providing lab facilities for extraction and fractionation.

\section{References}

[1] S. K. Agarwal, S. S. Singh, V. Lakshmi, S. Verma, and S. Kumar, "Chemistry and Pharmacology of rhubarb (Rheum species). A review," Journal of Scientific and Industrial Research, vol. 60, no. 1, pp. 1-9, 2001.

[2] Y. Kashiwada, G.-I. Nonaka, I. Nishioka, and T. Yamagishi, "Galloyl and hydroxycinnamoyl glucoses from Rhubarb," Phytochemistry, vol. 27, no. 5, pp. 1473-1477, 1988.

[3] F. Li, S. C. Wang, X. Wang et al., "Novel exploration of cathartic pharmacology induced by rhubarb," China Journal of Chinese Materia Medica, vol. 33, no. 4, pp. 481-484, 2008.

[4] V. Rajkumar, G. Guha, and R. A. Kumar, "Antioxidant and anticancer potentials of rheum emodi rhizome extract," EvidencedBased Complementary and Alternative Medicine, vol. 2011, 9 pages, 2011.

[5] R. Hina, W. Begum, F. Anjum, and H. Tabasum, "Rheum emodi (Rhubarb), A fascinating herb," Journal of Pharmacognosy and Phytochemistry, vol. 3, no. 2, pp. 89-94, 2014.

[6] Y. Ding, L. Zhao, H. Mei et al., "Exploration of Emodin to treat alpha-naphthylisothiocyanate-induced cholestatic hepatitis via anti-inflammatory pathway," European Journal of Pharmacology, vol. 590, no. 1-3, pp. 377-386, 2008.

[7] M. S. Lee and C. B. Sohn, "Anti-diabetic properties of chrysophanol and its glucoside from rhubarb rhizome," Biological \& Pharmaceutical Bulletin, vol. 31, no. 11, pp. 2154-2157, 2008.
[8] M. A. Magda and M. G. Nehad, "Antimicrobial efficacy of Rheum palmatum, Curcumalongaand Alpinia officinarumextracts againstsome pathogenic microorganisms," African Journal of Biotechnology, vol. 10, no. 56, pp. 12058-12063, 2011.

[9] Z. P. Xu, Z. J. Lu, J. H. Chen, X. Y. Deng, Y. Z. Mao, and X. Huo, "The effect of rhubarb ethanol-extract on hyperlipidemia and liver fatty in rabbits," Chinese Journal of Applied Physiology, vol. 23, no. 3, pp. 375-379, 2007.

[10] X. Xing, Y. Zhao, W. Kong et al., "Investigation of the "dose-time-response" relationships of rhubarb on carbon tetrachloride-induced liver injury in rats," Journal of Ethnopharmacology, vol. 135, no. 2, pp. 575-581, 2011.

[11] J. K. Achakzai and M. Anwar, "GC-MS analysis and antileishmanial activity of dichloromethane fraction of allium cepa (DFAC) in vitro," International Journal of Pharma and Bio Sciences, vol. 7, no. 2, pp. 40-51, 2016.

[12] J. Bakht, S. Khan, and S. Mohammad, "Antimicrobial potentials of fresh Allium cepa against gram positive and gram negative bacteria and fungi," Pakistan Journal of Botany, vol. 45, pp. 1-6, 2013.

[13] D. A. Scudiero, R. H. Shoemaker, K. D. Paull et al., "Evaluation of a soluble tetrazolium/formazan assay for cell growth and drug sensitivity in culture using human and other tumor cell lines," Cancer Research, vol. 48, no. 17, pp. 4827-4833, 1988.

[14] S. L. Helfand, J. Werkmeister, and J. C. Roder, "Chemiluminescence response of human natural killer cells: I. the relationship between target cell binding, chemiluminescence, and cytolysis," The Journal of Experimental Medicine, vol. 156, no. 2, pp. 492505, 1982.

[15] T. M. de Almeida Alves, A. Fonseca Silva, M. Brandão et al., "Biological screening of Brazilian medicinal plants," Memórias do Instituto Oswaldo Cruz, vol. 95, no. 3, pp. 367-373, 2000.

[16] B. Kivack, T. Mert, and H. Tansel, "Antimicrobial and Cytotoxic activities of Ceratonia siliqua L. extracts," Turkish Journal of Biology, vol. 26, pp. 197-200, 2001.

[17] J. L. Carballo, Z. L. Hernandez-inda, P. Perez, and M. D. GarciaGravalos, "A comparison between two brine shrimp assays to 
detect in vitro cytotoxicity in marine natural products," Bio Med Central Biotechnology, vol. 2, pp. 1-10, 2002.

[18] E. Ahmed El-Wakil, M. Mohamed El-Sayed, E. El-Sayed, and Abdel-Lateef, "GC-MS Investigation of Essential oil and antioxidant activity of Egyptian White Onion (Allium cepa L.)," International Journal of Pharma Sciences and Research IJPSR, vol. 6 , no. 3, 2015. 

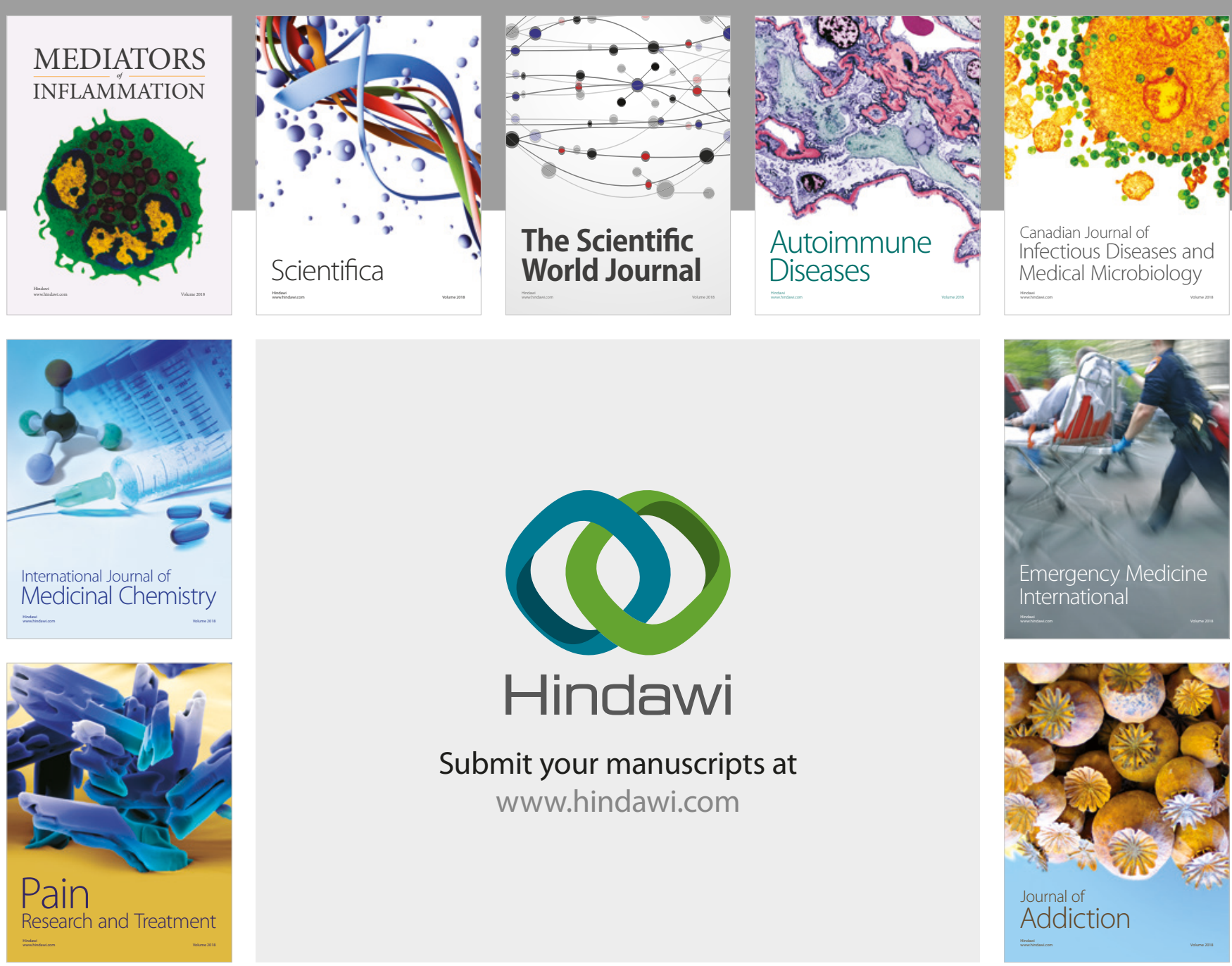

Canadian Journal of
Infectious Diseases and Medical Microbiology

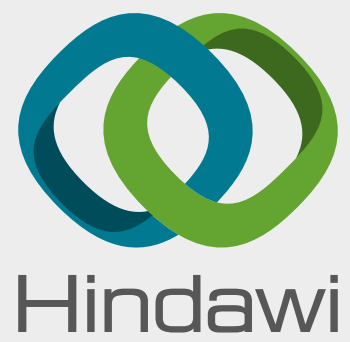

Submit your manuscripts at

www.hindawi.com
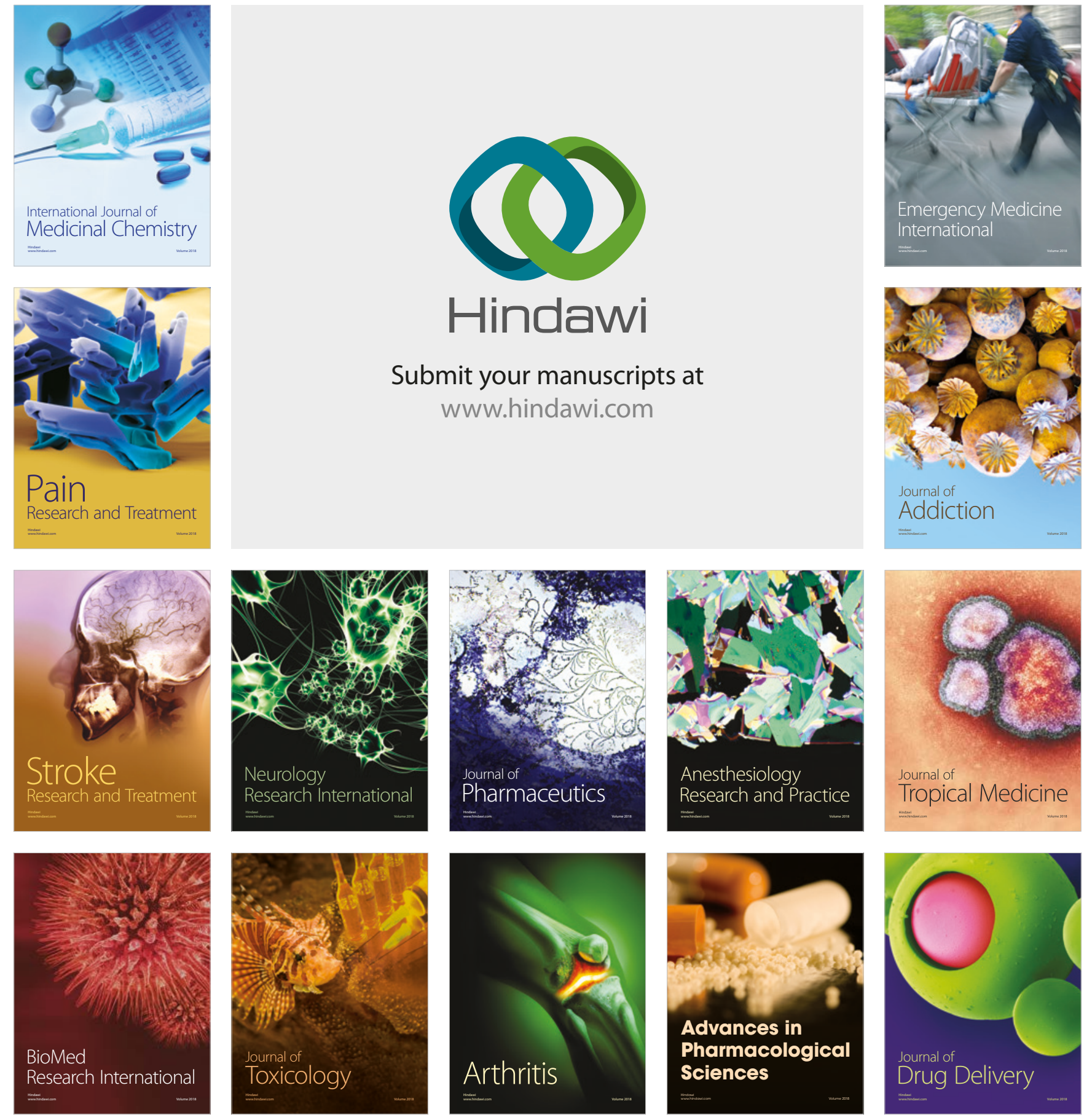